\title{
CONTAMINATION OF BIOAEROSOL IN THE CONFECTIONERY FACILITY WITH Enterobacteriaceae MEMBERS
}

\section{ZANIECZYSZCZENIE BIOAEROZOLU W ZAKŁADZIE CUKIERNICZYM BAKTERIAMI Z RODZINY Enterobacteriaceae}

\author{
Independent Department of Biotechnology and Molecular Biology, University of Opole, Poland
}

\begin{abstract}
Streszczenie. Mikroorganizmy w powietrzu środowiska produkcji stanowią jeden z głównych czynników prowadzących do zanieczyszczenia produktu lub obniżenia jego jakości. Dobra praktyka produkcyjna zakłada monitorowanie czystości sanitarnej środowiska produkcji. Istotne jest oszacowanie źródła zanieczyszczenia oraz wpływu warunków mikroklimatycznych na zmiany liczebności mikroorganizmów w powietrzu. Celem przeprowadzonych badań była ocena udziału bakterii rodziny Enterobacteriaceae w ogólnej liczbie mikroorganizmów w bioaerozolu hal produkcyjnych $w$ trakcie produkcji. Badania przeprowadzono w zakładzie cukierniczym w trakcie produkcji, w dwóch halach technologicznych (H.1, H.2). W każdej z hal o zróżnicowanych etapach produkcji i liczbie pracowników wyznaczono 7 punktów poboru próbek. Powietrze do analiz pobierano metodą zderzeniową za pomocą impaktora MAS-100. Płytki Petriego inkubowano w standardowych dla ogólnej liczby bakterii warunkach $\left(22^{\circ} \mathrm{C}, 72 \mathrm{~h}\right)$. Izolaty barwiono metodą Grama, a przynależność do rodziny Enterobacteriaceae różnicowano poprzez analizę profili biochemicznych. Wyniki podano $\mathrm{w}$ jtk $\cdot \mathrm{m}^{-3}$. Analizę wpływu miejsca poboru próbki i hali na liczebność bakterii w powietrzu oceniono, stosując dwuczynnikową analizę wariancji (ANOVA). Korelację pomiędzy liczbą pracowników, liczebnością bakterii a parametrami mikroklimatycznymi oceniono, wyznaczając współczynnik korelacji Pearsona. Analizę statystyczną przeprowadzono w programie R Studio. Liczba pracowników była pozytywnie skorelowana z liczebnością bakterii w bioaerozolu. Bakterie Enterobacteriaceae dominowały w miejscach o największym zagęszczeniu pracowników, czyli na stanowiskach ręcznego sortowania i pakowania wyrobu gotowego.
\end{abstract}

Key words: Bioaerosol, Enterobacteriaceae, confectionery facility, workers.

Słowa kluczowe: bioaerozol, Enterobacteriaceae, pracownicy, zakład cukierniczy.

\section{INTRODUCTION}

Presence of microorganisms in the food production environment is the most important concern for food quality management. The sources of foodborne pathogens may be divided into the primary contamination, which comes from: raw materials, technological water, packages or secondary contamination causes by factors presence in the food production environment as: air conditioning systems, outdoor environment, workers and inappropriate cleaning operations (Shale and Lues 2007). The physicochemical conditions of processing environment, such as relative humidity or temperature, influence on the presence of

Corresponding author - Adres do korospondencji: Magdalena Kręcidło, Independent Department of Biotechnology and Molecular Biology, University of Opole, Kardynała Bolesława Kominka 6, 46-020 Opole, Poland, e-mail: krecidlo.m@gmail.com 
microorganisms in the foodstuff production area. Air is one of the most important sources of microbial contamination transmission in both outdoor and indoor environment (Wijnand et al. 2012). Bacterial and fungal cells are suspended in the air on water drops, organic dust or mineral dust. When microbial cell are associated with dust particles or condensation droplets, these organisms can be dispersed in a food processing unit as bioaerosols and may be deposited onto food contact surfaces (Brandl et al. 2013). Bioaerosols are composed of biological particles deposited in the air. The diameter of bioaerosols ranges from $0.3 \mu \mathrm{m}$ to $100 \mu \mathrm{m}$. The airborne particles including bacterial cells, part of fungal mycelium, spores, viruses, hairs and epidermal cells (Smets et al. 2016).

In the food industry dust and using of powdery materials (e.g. flour, powder milk, powder sugar or grains) generate proper conditions to persistence of microorganisms in the air. The fact of positive correlation between organic dust emission and microbial contamination is explained by many reports from feedstuff manufactories, agricultural activities, dairy facilities, bakery, flour processing facilities (Mandal and Brandl 2011; Dungan 2012; Lücking et al. 2013; Garcia et al. 2013).

The aim of study was to assess the occurrence of Enterobacteriaceae in composition of bacteriological bioaerosol from technological halls during production in relation to microclimatic parameters.

\section{MATERIAL AND METHODS}

Sampling sites. The study was conducted at the confectionery facility located in Opolskie voivodeship. The confectionary facility was a close complex of buildings contained following areas: two technological halls, products warehouse and raw materials warehouse, social and administration workers area. The sampling was carried out during production and workers activity. Sample sites selected for the study was situated indoor in two technological halls assigned as H.1 ( $n=21), H .2(n=21)$. In the first hall petit fours were produced, while in the second hall the wafers. Outdoor air was the control case $(n=4)$. Air samples were collected at 7 selected sites in each technological hall $(\mathrm{H} .1 .1, \mathrm{H} .1 .2, \mathrm{H} .1 .3, \mathrm{H} .1 .4, \mathrm{H} .1 .5, \mathrm{H} .1 .6, \mathrm{H} .1 .7$, H.2.1, H.2.2, H.2.3, H.2.3, H.2.5, H.2.6, H.2.7). Sites were selected by type of processing operation and number of workers. In the work the technological terminology of processes and products were used. The temperature and air humidity were controlled in both hall by use of continues temperature and humidity recorder AR236 (APAR, Poland).

Collection and analysis of airborne bacteria. The air samples were taken by volumetric method with using one-state impactor - MAS-100 (Merck, USA). The scheme of setting sampling devices was $1 \mathrm{~m}$ high, $1 \mathrm{~m}$ from walls and technological line. The volume of air impacted on to the head of the device was $100 \mathrm{dm}^{3}$ for each sample. The laminar air flow was directed onto the agar surface of Petri dishes containing appropriate medium for tested microorganism group. Microbial count in each sample was determined by culture depend methods. For estimating the total number of bacteria the PCA medium (Plate Count Agar, Biocorp, Poland) was used. Plates were incubated at $22^{\circ} \mathrm{C}$ for $72 \mathrm{~h}$. The Hektoen medium (Biocorp, Poland) was applied to confirm the number of Enterobacteriaceae. Plates were incubated at $37^{\circ} \mathrm{C}$ for $48 \mathrm{~h}$. According to the impactor guideline the Pr value (Probable Statistical Total) was estimated with the use of the Feller's formula (Feller 1950). The isolates 
were diversified by their morphological (Gram's staining technique) and biochemical properties (Szewczyk 2013). Estimation of bacteriological quality of air was conducted by measurement of the total number of three bacterial groups: TNB - total number of culturable bacteria; E - total number of Enterobacteriaceae members; GNR - number of Gram-negative bacteria.

Data analysis. The results were given as the number of colony forming units in the $1 \mathrm{~m}^{3}$ of air. Statistical analysis were performed in the R Studio (The R foundation, Austria) and in MS Excell (Microsoft Corporation, USA). One-way analysis of variance (ANOVA test) was performed to analyse number of bacteria as a function of sampling site. The data were shown as averages and standard deviations from three repeats for each indoor samples and four repeats for outdoor sample. The correlation coefficient (Pearson's) between biotic (TNB, E, NW) and microclimate parameters (air temperature, relative humidity) was also calculated. The $P$ values less than 0.05 are considered to be significant.

\section{RESULTS}

Measurement of environmental factors. The measurement of physicochemical environmental factors, as temperature and relative humidity, was conducted simultaneously with collection of air samples. Temperature and relative humidity were higher at line of wafer biscuits production than at line of petit fours production (Table 1).

Table 1. The physical parameters of selected technological hall points and the description of unit operations conducted at each of this places

Tabela 1. Parametry mikroklimatyczne w poszczególnych punktach hal technologicznych oraz opis operacji jednostkowych wykonywanych w tych miejscach

\begin{tabular}{|c|c|c|c|c|c|}
\hline \multirow{2}{*}{$\begin{array}{c}\text { Symbol } \\
\text { of sampling site } \\
\text { Symbol miejsca } \\
\text { poboru }\end{array}$} & \multirow[t]{2}{*}{$\begin{array}{l}\text { Technological operations Operacje } \\
\text { technologiczne }\end{array}$} & \multicolumn{2}{|c|}{$\begin{array}{c}\text { Humidity } \\
\text { Wilgotność } \\
{[\%]}\end{array}$} & \multicolumn{2}{|c|}{$\begin{array}{c}\text { Temperature } \\
\text { Temperatura } \\
{\left[{ }^{\circ} \mathrm{C}\right]}\end{array}$} \\
\hline & & $\mathrm{x}$ & $\pm S D$ & $\mathrm{X}$ & $\pm S D$ \\
\hline H.1.1 & $\begin{array}{l}\text { weighting and mixing of raw materials } \\
\text { ważenie i mieszanie surowców }\end{array}$ & 50 & \pm 2 & 18 & \pm 1 \\
\hline H.1.2 & washing of dishes - punkt mycia & 50 & \pm 2 & 18 & \pm 1 \\
\hline H.1.3 & $\begin{array}{l}\text { petit fours slicing and backing } \\
\text { krojenie i pieczenie ciastek kruchych }\end{array}$ & 50 & \pm 2 & 18 & \pm 1 \\
\hline H.1.4 & $\begin{array}{l}\text { petit fours slicing and backing } \\
\text { krojenie i pieczenie ciastek kruchych }\end{array}$ & 51 & \pm 2 & 19 & \pm 1 \\
\hline H.1.5 & petit fours manual sorting and packing & 51 & \pm 2 & 20 & \pm 1 \\
\hline H.1.6 & ręczne pakowanie i sortowanie ciastek kruchych & 50 & \pm 3 & 21 & \pm 1 \\
\hline H.1.7 & $\begin{array}{l}\text { area between } \mathrm{H} 1 \text { and } \mathrm{H} 2 \\
\text { korytarz pomiędzy } \mathrm{H} 1 \text { a } \mathrm{H} 2\end{array}$ & 52 & \pm 5 & 21 & \pm 1 \\
\hline H.2.1 & $\begin{array}{l}\text { wafer biscuits manual sorting and packing } \\
\text { ręczne sortowanie i pakowanie wafli }\end{array}$ & 55 & \pm 3 & 21 & \pm 1 \\
\hline H.2.2 & wafer biscuits coating - oblewanie wafli polewą & 56 & \pm 2 & 21 & \pm 1 \\
\hline H.2.3 & wafer biscuits coating - oblewanie wafli polewą & 60 & \pm 1 & 22 & \pm 0 \\
\hline H.2.4 & wafer biscuits slicing - krojenie wafli & 63 & \pm 2 & 23 & \pm 1 \\
\hline H.2.5 & wafer biscuits filling - wypełnianie wafli & 69 & \pm 7 & 24 & \pm 1 \\
\hline H.2.6 & wafer biscuits baking - pieczenie wafli & 74 & \pm 6 & 25 & \pm 1 \\
\hline H.2.7 & wafer biscuits baking - pieczenie wafli & 75 & \pm 5 & 26 & \pm 1 \\
\hline
\end{tabular}

$\mathrm{X} \pm \mathrm{SD}-$ mean \pm standard deviation - średnia \pm odchylenie standardowe. 
The highest temperature and humidity were obtained for H.2.6 and H.2.7 sites where wafer baking operations were conducted. Variations in temperature and humidity between first and second hall resulted from differences in the backing process and distinction of water contents in both raw doughs.

The occurrence of bacteria in the production area. The highest rate of bacterial contamination of air $\left(1.110^{3} \mathrm{CFU} \cdot \mathrm{m}^{-3}\right)$ was noted on first hall, at the sampling site, where workers sorted and packed petit fours (Table 2, H.1.5). Bacterial number was the lowest in the second hall $(\mathrm{H} 2)$, following the site of wafer biscuits filling and slicing (Table 2, H.2.4 and H.2.5). At the other processing sites, the overall numbers of bacteria were $1.9-5.6 \mathrm{x}$ $x 10^{5} \mathrm{CFU} \cdot \mathrm{m}^{-3}$. In general the total number of bacteria indoor, except the sites of the petit fours manual packing and sorting, was lower than bacterial contamination of the outdoor environment near the facility. The occurrence of Gram-negative bacteria in the total number of bacteria depends on step of petit fours and wafers production (Table 3 ) and were between 4.9 and $17.4 \%$ in the first hall, and from 2.4 to $30 \%$ in the second hall. Enterobacteriaceae members dominated in the Gram-negative bacteria population at following sites: the petit fours baking site (Table 2, H.1.3) and at the point of the dishes washing (Table 2, H.1.2). On the production line of the wafer biscuits $(\mathrm{H} .2)$ the highest percentage of Enterobacteriaceae in the air was noted for sites where wafers were filled (Table 2, H.2.5) and sliced (Table 2, H.2.4). Based on the obtained results it is concluded that presence of faecal bacteria depends on an improper hygiene in the production area.

Table 2. Evaluation of the bacteriological quality of technological sites in regard to the number of workers Tabela 2. Ocena jakości bakteriologicznej stanowisk technologicznych, z uwzględnieniem liczby pracowników

\begin{tabular}{|c|c|c|c|c|c|c|c|c|}
\hline & \multirow[t]{2}{*}{$\begin{array}{l}\text { Sampling sites } \\
\text { Miejsce poboru }\end{array}$} & \multicolumn{3}{|c|}{$\begin{array}{c}\text { TNB } \\
{\left[\times 10^{2} \mathrm{CFU} \cdot \mathrm{m}^{-3}\right]}\end{array}$} & \multirow[t]{2}{*}{$1 / 0$} & \multirow{2}{*}{$\begin{array}{l}\text { GNR } \\
{[\%]}\end{array}$} & \multirow{2}{*}{$\begin{array}{c}E \\
{[\%]}\end{array}$} & \multirow[t]{2}{*}{ NW } \\
\hline & & & \pm & SD & & & & \\
\hline H.1.1 & $\begin{array}{l}\text { weighing and mixing of raw materials } \\
\text { ważenie i mieszanie surowców }\end{array}$ & 5.57 & \pm & 0.18 & 1.01 & 4.04 & 3.27 & 1 \\
\hline H.1.2 & washing of dishes - punkt mycia & 3.37 & \pm & 0.08 & 0.61 & 11.88 & 11.88 & 2 \\
\hline H.1.3 & petit fours slicing and backing & 1.87 & \pm & 0.15 & 0.34 & 17.41 & 17.41 & 1 \\
\hline H.1.4 & krojenie i pieczenie ciastek kruchych & 2.37 & \pm & 0.11 & 0.43 & 15.85 & 15.85 & 3 \\
\hline H.1.5 & $\begin{array}{l}\text { petit fours manual sorting and } \\
\text { packing - ręczne pakowanie }\end{array}$ & 11.37 & \pm & 0.29 & 2.06 & 12.80 & 0.94 & 2 \\
\hline H.1.6 & i sortowanie ciastek kruchych & 4.60 & \pm & 0.32 & 0.83 & 13.04 & 7.37 & 3 \\
\hline H.1.7 & $\begin{array}{l}\text { area between } \mathrm{H} 1 \text { and } \mathrm{H} 2 \text { - korytarz } \\
\text { pomiędzy } \mathrm{H} 1 \mathrm{a} \mathrm{H} 2\end{array}$ & 3.70 & \pm & 0.32 & 0.67 & 16.22 & 0.70 & 0 \\
\hline H.2.1 & $\begin{array}{l}\text { wafer biscuits manual sorting and } \\
\text { packing - ręczne sortowanie } \\
\text { i pakowanie wafli }\end{array}$ & 1.47 & \pm & 0.11 & 0.27 & 28.98 & 12.63 & 1 \\
\hline H.2.2 & wafer biscuits coating & 1.00 & \pm & 0.07 & 0.18 & 15.00 & 0.00 & 0 \\
\hline H.2.3 & oblewanie wafli polewą & 3.13 & \pm & 0.15 & 0.57 & 2.39 & 2.39 & 1 \\
\hline H.2.4 & $\begin{array}{l}\text { wafer biscuits slicing } \\
\text { krojenie wafli }\end{array}$ & 2.30 & \pm & 0.07 & 0.42 & 11.96 & 10.99 & 1 \\
\hline H.2.5 & $\begin{array}{l}\text { wafer biscuits filling } \\
\text { wypełnianie wafli }\end{array}$ & 2.89 & \pm & 0.23 & 0.52 & 14.72 & 14.72 & 2 \\
\hline H.2.6 & wafer biscuits baking & 3.23 & \pm & 0.25 & 0.59 & 22.42 & 11.20 & 1 \\
\hline $\mathrm{H} .2 .7$ & pieczenie wafli & 2.87 & \pm & 0.27 & 0.52 & 17.44 & 12.34 & 1 \\
\hline \multicolumn{2}{|c|}{$\begin{array}{l}\text { Average for production area } \\
\text { Średnia dla obszaru produkcji }\end{array}$} & 3.55 & \pm & 0.17 & 0.64 & 14.58 & 8.69 & 1.36 \\
\hline
\end{tabular}

I/O - ratio of bacteria concentration in indoor to bacteria concentration in outdoor air - stosunek ogólnej liczby bakterii w powietrzu na zewnątrz i wewnątrz zakładu; TNB - total number of bacteria - ogółna liczba bakterii; GRN - Gram-negative rods - Gram-ujemne pałeczki; E - Enterobacteriaceae; NW - number of wolkers - liczba pracowników. 
Table 3. Statistical significance of various factor influence on the total number of bacteria estimated by two-way ANOVA

Tabela 3. Istotność statystyczna wpływu poszczególnych czynników na ogólną liczbę bakterii mezofilnych, oszacowana na podstawie dwuczynnikowej analizy wariancji

\begin{tabular}{lccccc}
\hline & Df & $\begin{array}{c}\text { Square sum } \\
\text { Suma kwadratów }\end{array}$ & $\begin{array}{c}\text { F value } \\
\text { Wartość F }\end{array}$ & $\operatorname{Pr}(>F)$ & $p$ \\
\hline Hall - Hala & 1 & 726560.51 & 1290.26 & $3.68 \cdot 10^{-33}$ & $>0.001$ \\
Site - Miejsce & 6 & 1395980.19 & 413.17 & $1.11 \cdot 10^{-35}$ & $>0.001$ \\
Hall : Site - Hala : Miejsce & 6 & 1243291.94 & 367.98 & $1.20 \cdot 10^{-34}$ & $>0.001$ \\
Residuals - Reszty & 42 & 23650.67 & & & \\
\hline
\end{tabular}

Relationship between microclimate parameters and biotic factors. The relationship between the total number of bacteria and the environmental microclimate factors (temperature, relative humidity) are shown in Figure 1. Air temperature and relative humidity were weakly, negatively correlated with the total number of bacteria, while the number of Gram-negative rods, Enterobacteriaceae and workers were not correlated with microclimatic parameters. The count of Enterobacteriaceae shown moderate, positive correlation with number of workers. Surprising, the number of Gram-negative bacteria in the air shown strong, positively relationship with overall numbers of bacteria, but Enterobacteriaceae members was not correlated with concentration of total bacteria in the air.

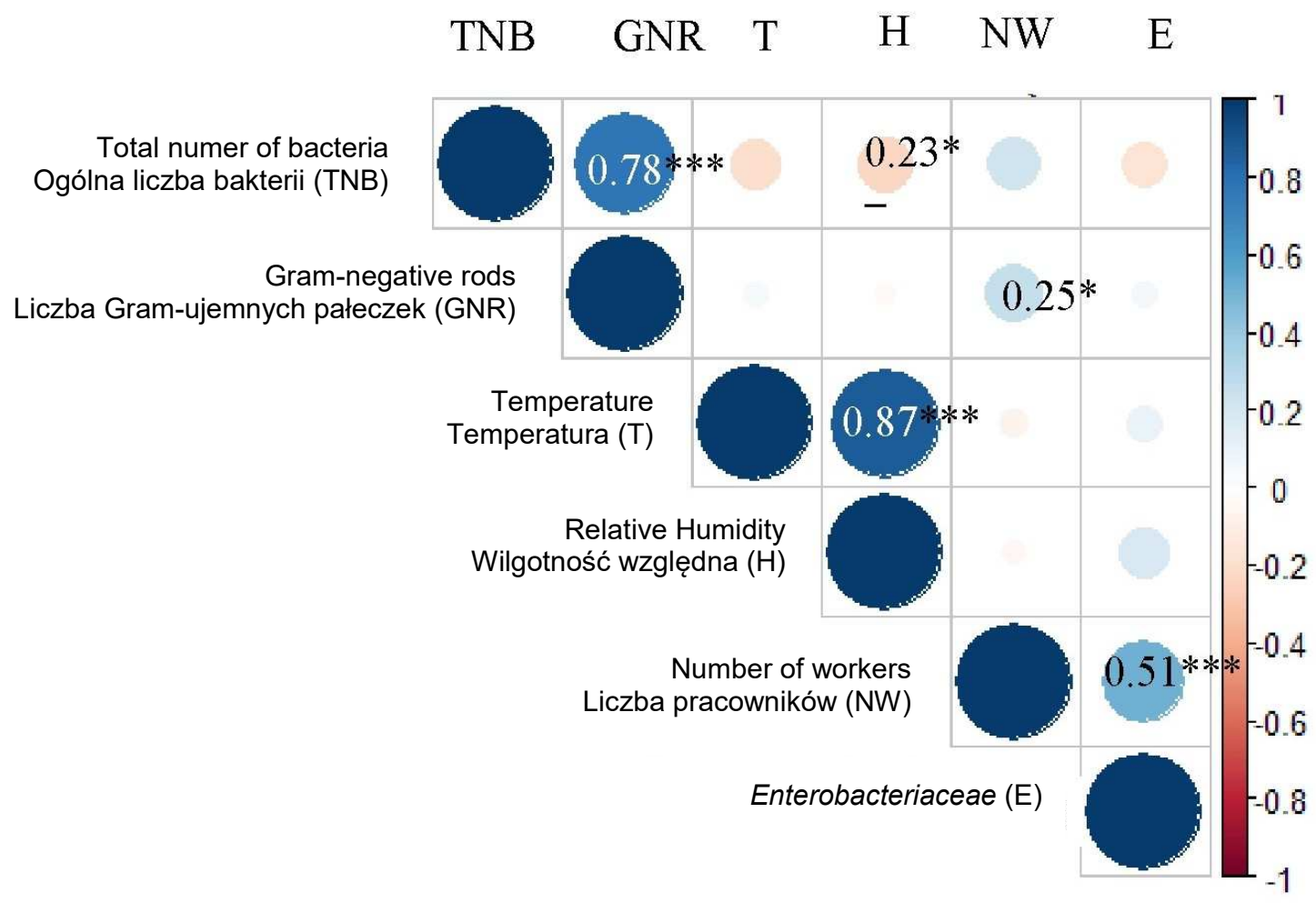

Fig. 1. Pearson's correlation coefficients for microclimate and biotic parameters in the technological sites. Statistical significance for: ${ }^{*} p<0.05,{ }^{* *} p<0.01,{ }^{* * *} p<0.001$

Ryc. 1. Współczynnik korelacji Pearsona pomiędzy parametrami fizycznymi przestrzeni produkcyjnej a oszacowanymi parametrami biotycznymi środowiska produkcji. Istotność statystyczna dla: ${ }^{*} p<0,05$, ${ }^{* *} p<0,01,{ }^{* * *} p<0,001$ 


\section{DISCUSSION}

Contamination of foodstuffs by airborne microorganisms may be dangerous to the health of potential consumers, the quality of the product being decreased and substantial financial losses in a company being caused (Asefa et al. 2009). Direct microbial contamination of food product by the airborne bacteria may or may not be significant, depending on the type of product and process. Bakery and confectionery products have low water activity $\left(a_{w}\right)$ which protect them of microbial growth (Kornacki 2014). However, it is necessary to determine the main factors which influence on the concentration and composition of microbial community in the air of food facilities.

The estimation of influent factors may help with implementation the air quality standards in facilities in regarding to the character of production, the technology employed and the specific branch of industry (Beletsiotis et al. 2011). The number of microorganisms in $1 \mathrm{~m}^{3}$ of air obtained by Brandl et al. (2014) from milk processing facility was lower (>100 CFU $\cdot \mathrm{m}^{-3}$ ) than mean number of airborne bacteria in this study $\left(355 \mathrm{CFU} \cdot \mathrm{m}^{-3}\right.$ ). However, the processing of milk and production of milk powder are more susceptible to microbial contamination and require high hygiene standards. Brandl et al. (2013) also obtained the increase of bioaerosol concentration during the packing operations and considered that the level of airborne microorganism depended on the location sites. In their previous works Brandl et al. (2005) highlighted that the generation of bioaerosols was associated with anthropogenic activity. Hao et al. (2017) found that the number of people and human activities had positive correlations with the concentration of bacterial bioaerosols, but this relationship did not occur for the fungal bioaerosols.

Analysis of the human presence and concentration of studied bacterial group in the confectionary facility showed the positive correlation between the number of workers and number of airborne Enterobacteriaceae. In our study did not occur the significance relation between the number of workers and total number of bacteria or number of Gram-negative rods. Relationship between the enteritic coliform and the number of workers, if will be confirmed in the future studies, may be the important indicator of hygiene rate in the facility. The number of Enterobacteriaceae is used as indicator of hygiene status and quality of finished product for milk processing facilities (Hervert et al. 2016). One of the main factors influences on the bioaerosol composition and concentration is outdoor air flow (Adams et al. 2013). In the confectionary facility halls the radio of indoor airborne bacteria to outdoor bacteria was mostly less than 1 .

Only in the sites of raw materials weighing and petit fours packing the concentration of bacteriological bioaerosol was higher in the indoor environment. In the technological halls poor negative correlation between relative humidity and total number of bacteria was obtained. Gao et al. (2016) also suggested that concentration of bioaerosol is negatively linked with the increase of relative humidity. This may be explained by higher level of microorganism cell deposition with water drops onto surfaces. However, Tsai and Liu (2008) obtained positive correlation between concentration of fungal bioaerosol and relative humidity in the noodle production facility and concluded that humidity higher than $60-70 \%$ may enhanced microbial growth. 


\section{CONCLUSIONS}

The results of this study show a high level of bacteriological contamination of the air in the site of sorting and packing the petit fours. The number of isolates from obtained bacterial groups (TNB, GNR, E) was various and depended on the sampling site and technological hall. Concentration of bacterial bioaerosol was not correlated with the numbers of workers, while the number of Enterobacteriaceae members in the air were positively linked with number of workers. This suggested, that human presence and activity impacted on increase of the concentration of coliforms bacteria but did not impact on total number of bacteria. Microclimatic parameters of technological halls also not significantly influenced on total number of bacteria and number of gram negative rods, especially coliforms. The methods of raw doughs processing and doughs composition influenced on the microclimatic parameters of technological hall. Obtained result may help to improve the hygiene standards in the facility by the implementation of protection clothes for workers.

\section{REFERENCES}

Adams R.I., Miletto M., Taylor J.W., Bruns T.D. 2013. Dispersal in microbes: Fungi in indoor air are dominated by outdoor air and show dispersal limitation at short distances. ISME J. 7(7), 1262-1273.

Asefa D.T., Langsrud S., Gjerde R.O., Kure C.F., Sidhu M.S., Nesbakken T., Skaar I. 2009. The performance of SAS-super-180 air sampler and settle plates for assessing viable fungal particles in the air of dry-cured meat production facility. Food Control. 20(11), 997-1001.

Beletsiotis E., Ghikas D., Kalantzi K. 2011. Incorporation of microbiological and molecular methods in HACCP monitoring scheme of molds and yeasts in a Greek dairy plant: A case study. Proc. Food Sci. 1, 1051-1059.

Brandl H., Ziegler D., Stephan R., Mandal J., Lehner A. 2013. Distribution and identification of culturable airborne microorganisms in a Swiss milk processing facility microorganisms in a Swiss milk processing facility (December). J. Dairy Sci. 97, 240-246.

Brandl H., Bachofen R., Bischoff M. 2005. Generation of bioaerosols during manual mail unpack-ing and sorting. J. Appl. Microbiol. 99: 1099-1107.

Dungan R.S. 2012. Use of culture-independent approach to characterize aerosolized bacteria near open-freestall dairy operation. Environ. Int. 41, 8-14.

Feller W. 1950. An introduction to the probability theory and its application. New York, John Wiley \& Sons.

Gao M., Yan X., Qiu T., Han M., Wang X. 2016. Variation of correlations between factors and culturable airborne bacteria and fungi. Atmos. Environ. 128, 10-19.

Garcia J., Bennett D.H., Tancredi D., Schenker M.B., Mitchell D., Reynolds S.J., Mitloehner F.M. 2013. Occupational exposure to particulate matter and endotoxin for California dairy workers. Int. J. Hyg. Environ. Heal. 216(1), 56-62.

Heo K.J., Lim C.E., Kim H.B., Lee B.U. 2017. Effects of human activities on concentrations of culturable bioaerosols in indoor air environments. J. Aerosol Sci. 104, 58-65.

Hervert C.J., Martin N.H., Boor K.J., Wiedmann W. 2016. Survival and detection of coliforms, Enterobacteriaceae, and gram-negative bacteria in Greek yogurt. J. Dairy Sci. 100, 950-960.

Kornacki J.F. 2014. Airborne contamination. A microbiologist's perspective. Food Saf. 6, 12-16.

Lücking G., Stoeckel M., Atamer Z., Hinrichs J., Ehling-Schulz M. 2013. Characterization of aerobic spore-forming bacteria associated with industrial dairy processing environments and product spoilage. Int. J. Food Microbiol. 166(2), 270-279. 
Mandal J., Brandl H. 2011. Bioaerosols in indoor environments. A review with special reference to residential and occupational locations. Open Environ. Biol. Monit. J. 4, 83-96.

Shale K., Lues J. F.R. 2007. The etiology of bioaerosols in food environments. Food Rev. Int. 23, 73-90.

Smets W., Moretti S., Denys S., Lebeer S. 2016. Airborne bacteria in the atmosphere. Presence, purpose, and potential. Atm. Environ. 139, 214-221.

Szewczyk E.M. 2013. Pałeczki jelitowe Enterobacteriaceae, w: Diagnostyka bakteriologiczna. Ed. E.M. Szewczyk. Warszawa, PWN, 131-155. [in Polish]

Tsai M., Liu H. 2008. Exposure to culturable airborne bioaerosols during noodle manufacturing in central Taiwan. Sci. Total Environ. 407(5), 1536-1546.

Wijnand E.H., Dick C., Duchaine B.J. 2012. Bioaerosol exposure assessment in the workplace: the past, present and recent advances. J. Environ. Monit. 14, 334-339.

Abstract. Airborne microorganisms from the production environment may be one of the main factor which lead to contamination of finished product or lead to decreasing of food quality. Good manufacturing practice includes a monitoring of purity in the production environment. It is important to estimate the source of microbial contamination and the influence of microclimatic conditions on changes in the microbial population of the air. The aim of study was to assess the occurrence of Enterobacteriaceae in composition of bacteriological bioaerosol from technological halls during production. The study were conducted in the confectionary facility in two technological halls (H.1, H.2) during production. In each hall, where the different stages of production were ran and various number of workers were worked, was determined 7 sampling sites. The air samples were taken by volumetric method with using MAS-100 impactor. Petri dishes were incubated in the standard conditions for the aerobic bacteria $\left(22^{\circ} \mathrm{C}, 72 \mathrm{~h}\right)$. Isolates were stained by Gram's technique and the members of Enterobacteriaceae were diversified by analysis the biochemical properties. Two-way ANOVA tests were performed to analyse number of bacteria as a function of sampling site and production hall. The results were given as CFU $\cdot 1 \mathrm{~m}^{-3}$ of air. Statistical analysis were performed in the R Studio. The number of workers had positive correlations with the concentrations of bacterial bioaerosols. Enterobacteriaceae dominated in the sectors with the higher number of workers i.e. in sector hand - sorting and packaging of finished products. 